\title{
Lack of sex differences in gonadotropin-releasing hormone (GnRH) neuron potassium currents and excitability
}

R. Anthony DeFazio ${ }^{1}$ and Suzanne M. Moenter ${ }^{1,2,3}$

Departments of Molecular \& Integrative Physiology ${ }^{1}$, Obstetrics and Gynecology ${ }^{2}$, and Internal Medicine $^{3}$, University of Michigan, Ann Arbor, MI.

Abbreviated title: Excitability and $\mathrm{K}^{+}$currents in $\mathrm{GnRH}$ neurons

Corresponding author: R. Anthony DeFazio, Ph.D., Department of Molecular and Integrative Physiology, University of Michigan, 7725 Med Sci II, 1137 E. Catherine St, Ann Arbor, MI 48109-5622

734-647-1755 (voice), 734-936-8813 (fax) defazio@umich.edu

Number of figures: 5

Number of tables: 6

Number of words: abstract 248, introduction 627, discussion 1685.

Abbreviations: $\mathrm{GnRH}$, gonadotropin-releasing hormone; $\mathrm{LH}$, luteinizing hormone; 4AP, 4aminopyridine; OVX, ovariectomized; ORC, orchidectomized; GDX, gonadectomized; AHP, afterhyperpolarization, FWHM, full width at half maximum

Acknowledgements: We thank Elizabeth Wagenmaker and Laura Burger for expert technical assistance and Joseph Starrett, Elizabeth Wagenmaker and Jennifer Jaime Alvarez for editorial comments. We thank James L. Kenyon, University of Nevada, Reno, for the Excel spreadsheet used to calculate junction potentials.

Conflict of interest: The authors declare no competing financial interests.

Grant support: Supported by National Institute of Health/Eunice Kennedy Shriver National Institute of Child Health and Human Development R37HD34860 to SMM 


\section{Significance Statement}

23 The pattern of activity of gonadotropin-releasing hormone $(\mathrm{GnRH})$ neurons is crucial to

\section{Abstract}

Gonadotropin-releasing hormone $(\mathrm{GnRH})$ drives pituitary secretion of luteinizing hormone (LH) and follicle-stimulating hormone, which in turn regulate gonadal functions including steroidogenesis. The pattern of $\mathrm{GnRH}$ release and thus fertility depend on gonadal steroid feedback. Under homeostatic (negative) feedback conditions, removal of the gonads from either females or males increases the amplitude and frequency of $\mathrm{GnRH}$ release and alters the longterm firing pattern of these neurons in brain slices. The neurobiological mechanisms intrinsic to $\mathrm{GnRH}$ neurons that are altered by homeostatic feedback are not well studied and have not been compared between sexes. During estradiol positive feedback, which is unique to females, there are correlated changes in voltage-gated potassium currents and neuronal excitability. We thus hypothesized these same mechanisms would be engaged in homeostatic negative feedback. Voltage-gated potassium channels play a direct role in setting excitability and action potential properties. Whole-cell patch-clamp recordings of GFP-identified GnRH neurons in brain slices from sham-operated and castrated adult female and male mice were made to assess fast $\left(\mathrm{I}_{\mathrm{A}}\right)$ and slow $\left(\mathrm{I}_{\mathrm{K}}\right)$ inactivating potassium currents as well as action potential properties. Surprisingly, no changes were observed in most potassium current properties, input resistance or capacitance and this was reflected in a lack of differences in excitability and specific action potential properties. These results support the concept that, in contrast to positive feedback, steroid negative feedback regulation of $\mathrm{GnRH}$ neurons in both sexes is likely conveyed to $\mathrm{GnRH}$ neurons via mechanisms that do not induce major changes in the biophysical properties of these cells. reproductive success in both males and females. Direct comparison of $\mathrm{GnRH}$ neurons from mice of both sexes during negative feedback and after gonadectomy revealed few differences in potassium currents, excitability, and action potential properties. These results support the hypothesis that neurons presynaptic to $\mathrm{GnRH}$ neurons communicate negative feedback to these cells in a manner that does not alter their intrinsic biophysical properties. 


\section{Introduction}

32 The episodic release of $\mathrm{GnRH}$ from the brain is key to successful reproduction in both sexes.

$33 \mathrm{GnRH}$ regulates pituitary release of luteinizing hormone (LH) and follicle-stimulating hormone,

34 which activate gonadal functions including production of sex steroids. These steroids feed back

35 to regulate the pattern of $\mathrm{GnRH}$ release and pituitary response to $\mathrm{GnRH}$. Aspects of this

36 feedback system are well established as sexually differentiated, for example estradiol positive

37 feedback is exclusive to females under normal physiologic conditions and induces the

38 preovulatory surge of GnRH (Docke and Dorner, 1965; Sarkar et al., 1976; Moenter et al., 1991).

39 Other aspects appear similar between the sexes, including homeostatic negative feedback that

40 regulates episodic $\mathrm{GnRH}$ release and is critical for maintaining most reproductive processes in

41 both males and females. Gonadectomy increases $\mathrm{GnRH}$ and LH release (Leipheimer et al.,

42 1985; Levine et al., 1985; Karsch et al., 1987; Caraty and Locatelli, 1988; Condon et al., 1988;

43 Jackson and Kuehl, 2000; Czieselsky et al., 2016). The main circulating sex steroids providing

44 homeostatic feedback are sexually differentiated, specifically estradiol and progesterone in

45 females, depending on stage of the reproductive cycle, and testosterone in males. The

46 differences in circulating steroids are reduced in part in the brain by conversion of testosterone

47 to estradiol (Fisher et al., 1998; Sharma et al., 1999), and the efficacy of androgens and

48 estrogens in eliciting negative feedback in males varies with species (Plant, 1982; Levine and

49 Duffy, 1988; Tilbrook et al., 1999).

50 Regulation of episodic $\mathrm{GnRH}$ release is a key potential intervention point for the very different

51 goals of reversibly inhibiting reproduction for contraception and ameliorating central infertility.

52 Despite a similar hormonal response to the removal of peripheral sex steroid feedback by

53 gonadectomy, whether or not the underlying intrinsic changes in $\mathrm{GnRH}$ neurons that lead to

54 these increases are sexually differentiated is unknown. Studies in females have focused on the

55 mechanisms underlying estradiol positive feedback that is critical for inducing ovulation; many of

56 these have compared gonadectomized animals with open feedback loops to those with specific

57 steroid replacement (Wagner et al., 2001; Christian and Moenter, 2010; Dror et al., 2013; Liu et

58 al., 2017; Adams et al., 2018b; Adams et al., 2019; Wang et al., 2019). These studies have

59 revealed changes in both intrinsic $\mathrm{GnRH}$ neuron properties and fast synaptic input to these cells.

60 Studies of homeostatic negative feedback suggest that the firing pattern of $\mathrm{GnRH}$ neurons

61 varies during the reproductive cycle in females and when steroid feedback is disrupted by

62 gonadectomy in both sexes (Pielecka and Moenter, 2006; Pielecka et al., 2006; Silveira et al., 
63 2017). There are no direct comparisons, however, of $\mathrm{GnRH}$ neuron intrinsic properties between

64 intact males and females or how these are affected by gonadectomy.

65 A basic measure of the intrinsic biophysical properties of neurons is their excitability, defined as

66 the number of action potentials generated in response to varying current injections. In females,

67 this varies with cycle stage and with induction of daily LH surges by estradiol in ovariectomized

68 mice (Adams et al., 2018b; Adams et al., 2019) but this parameter has not been characterized

69 in males. Voltage-gated potassium channels are widely recognized as regulators of excitability

70 (Johnston et al., 2010) and have been targeted clinically. For example, blocking a fraction of

71 potassium channels with 4-aminopyridine (4AP) increases the excitability of motor neurons in

72 amyotropic lateral sclerosis and multiple sclerosis and provides relief from the symptoms of

73 these diseases (Bakirtzis et al., 2018; Peikert et al., 2019). In many neurons, 4AP increases

74 input resistance and diminishes the ability of voltage-gated potassium channels to blunt action

75 potential firing and/or the membrane potential changes in response to synaptic inputs (Hoffman,

76 2013; DeFazio et al., 2019). Here we tested the hypotheses that voltage-gated potassium

77 currents are reduced and excitability of $\mathrm{GnRH}$ neurons increased by gonadectomy in both sexes.

\section{Materials and Methods}

79 All chemicals were acquired from Sigma-Aldrich (St. Louis, MO, USA) unless noted.

80 Animals. Mice expressing GFP under control of the $\mathrm{GnRH}$ promoter $(\mathrm{Tg}(\mathrm{GnRH} 1-$

81 EGFP)51Sumo MGI:6158457, GnRH-GFP mice, JAX 033639) were propagated in our colony.

82 All mice had ad libitum access to Harlan 2916 chow and water and were held at $21-23^{\circ} \mathrm{C}$ on a

83 14L:10D light cycle with lights on at 0300 eastern standard time. Adult mice 82-146 days old

84 were ovariectomized (OVX, females), orchidectomized (ORX, males) or sham operated under

85 isoflurane anesthesia with bupivacaine as a local analgesic. Studies were performed 5-7 days

86 after surgery. In sham-operated females, estrous cycles were monitored by vaginal cytology for

87 at least 10 days before experiments and diestrous mice were selected. Body, uterine and

88 seminal vesicle mass were recorded at the time of brain slice preparation to verify steroid status.

89 The Institutional Animal Care and Use Committee of the University of Michigan approved all

90 procedures. 
91 Brain slice preparation. All extracellular solutions were bubbled with $95 \% \mathrm{O}_{2} / 5 \% \mathrm{CO}_{2}$ throughout

92 the experiments and for at least $30 \mathrm{~min}$ before exposure to tissue. Coronal brain slices $(300 \mu \mathrm{m})$

93 containing the preoptic area (POA) were prepared with a Leica VT1200S (Leica Biosystems)

94 using modifications of previously described methods (DeFazio and Moenter, 2002). Brain slices

95 were obtained between 0730-0830 EST; recordings obtained between 0830-1430 EST. The

96 brain was rapidly removed and placed in ice-cold sucrose saline solution containing (in $\mathrm{mM}$ ):

97250 sucrose, $3.5 \mathrm{KCl}, 26 \mathrm{NaHCO}_{3}, 10 \mathrm{D}$-glucose, $1.25 \mathrm{Na}_{2} \mathrm{HPO}_{4}, 1.2 \mathrm{MgSO}_{4}$, and $3.8 \mathrm{MgCl}_{2}$

98 (350 mOsm). Slices were incubated for $30 \mathrm{~min}$ at room temperature $\left(\sim 21-23^{\circ} \mathrm{C}\right)$ in $50 \%$ sucrose 99 saline and $50 \%$ artificial cerebrospinal fluid (ACSF, containing (in $\mathrm{mM}$ ): $135 \mathrm{NaCl}, 3.5 \mathrm{KCl}, 26$

$100 \mathrm{NaHCO}_{3}, 10 \mathrm{D}$-glucose, $1.25 \mathrm{Na}_{2} \mathrm{HPO}_{4}, 1.2 \mathrm{MgSO}_{4}, 2.5 \mathrm{CaCl}_{2}, 315 \mathrm{mOsm}$, pH 7.4). Slices were 101 then transferred to $100 \%$ ACSF solution at room temperature for $0.5-5 \mathrm{~h}$ before recording. One

102 to three recordings were obtained per mouse with a minimum of 5 mice studied per group;

103 variation within a mouse was not less than that within a group.

104 Recording solutions and data acquisition. The pipette solution consisted of (in $\mathrm{mM}$ ): $125 \mathrm{~K}$ 105 gluconate, $20 \mathrm{KCl}, 10 \mathrm{HEPES}, 5 \mathrm{EGTA}, 0.1 \mathrm{CaCl}_{2}, 4 \mathrm{MgATP}$ and $0.4 \mathrm{NaGTP}, 305 \mathrm{mOsm}, \mathrm{pH}$

1067.2 with $\mathrm{NaOH}$; this solution is based on the native intracellular chloride concentration in $\mathrm{GnRH}$

107 neurons determined using gramicidin perforated-patch recordings (DeFazio et al., 2002). A 14.5

$108 \mathrm{mV}$ liquid junction potential was negated before each recording (Barry, 1994). During all

109 recordings, slices were continuously superfused at $2 \mathrm{ml} / \mathrm{min}$ with carboxygenated ACSF kept at

$110 \quad 30-31^{\circ} \mathrm{C}$ with an inline-heating unit (Warner Instruments). GFP-positive cells were visualized

111 with a combination of infrared differential interference contrast and fluorescence microscopy on

112 an Olympus BX50WI microscope. Recordings were made with an EPC-10 patch clamp amplifier

113 and a computer running PATCHMASTER software (HEKA Elektronik). For current-clamp

114 experiments, membrane voltage was acquired at $20 \mathrm{kHz}$ and filtered at $10 \mathrm{kHz}$; for voltage-

115 clamp experiments, current was acquired at $10 \mathrm{kHz}$ and filtered at $5 \mathrm{kHz}$. Input resistance,

116 series resistance, baseline current, and capacitance were monitored throughout experiments

117 from the membrane current response to a $20 \mathrm{~ms}, 5 \mathrm{mV}$ hyperpolarizing voltage step from -65

$118 \mathrm{mV}$ to monitor recording quality. All recordings with input resistances $\left(\mathrm{R}_{\mathrm{in}}\right)<0.5 \mathrm{G} \Omega$, series

119 resistances $\left(R_{s}\right)>20 M \Omega$, or unstable membrane capacitance $\left(C_{m}\right)$ were rejected. Results did

120 not depend on anatomical location of $\mathrm{GnRH}$ neurons within the POA. 
121 Experimental Design. Potassium currents, action potential properties and passive properties

122 were characterized in GFP-identified GnRH neurons in the preoptic area of brain slices

123 prepared from adult gonad intact and castrated mice of both sexes. Castrated mice were

124 studied 5-7 days post surgery; intact females were in diestrus.

125 Voltage-gated potassium current characterization. Potassium currents were isolated 126 pharmacologically during whole-cell voltage-clamp recordings by blocking fast sodium and

127 calcium channels as well as ionotropic receptors for GABA and glutamate ( $2 \mu \mathrm{M}$ tetrodotoxin

128 (TTX, Tocris), $300 \mu \mathrm{M} \mathrm{NiCl}_{2}, 20 \mu \mathrm{M}$ D-APV (Tocris), $10 \mu \mathrm{M}$ CNQX, and $100 \mu \mathrm{M}$ picrotoxin).

129 Membrane potential was held at $-65 \mathrm{mV}$ between voltage-clamp protocols. Series resistance 130 was monitored before compensation using the current response to a $5 \mathrm{mV}$ hyperpolarizing step.

131 Cells with $R_{S}>20 \mathrm{M} \Omega$ without compensation were discarded. Two potassium currents, $I_{A}$ and $I_{K}$,

132 were distinguished based on voltage dependence and time course. $\mathrm{I}_{\mathrm{A}}$ is a typical, rapidly-

133 inactivating potassium current that can be activated at membrane potentials that are

134 hyperpolarized to the threshold for action potential firing. I I also displays voltage-dependent

135 inactivation but this is restricted to more depolarized potentials and has a slower time course of

136 inactivation.

137 Activation and inactivation of $I_{A}$. Preliminary studies on $I_{A}$ showed that a $500 \mathrm{~ms}$ prepulse at -40

$138 \mathrm{mV}$ induced full inactivation, and a prepulse at $-100 \mathrm{mV}$ for $500 \mathrm{~ms}$ completely removed

139 inactivation. These two prepulses were combined with a series of voltage steps to isolate and

140 characterize $\mathrm{I}_{\mathrm{A}}$. To measure total potassium current, a $500 \mathrm{~ms}$ prepulse at $-100 \mathrm{mV}$ was first

141 applied to remove the inactivation of the fast transient component, followed by a family of

142 voltage steps (500 ms, $10 \mathrm{mV}$ intervals) from $-100 \mathrm{mV}$ to $+50 \mathrm{mV}$, and then a final step to -10

$143 \mathrm{mV}$ for $100 \mathrm{~ms}$. To inactivate $\mathrm{I}_{\mathrm{A}}$, the same step protocol was applied but with the $500 \mathrm{~ms}$

144 prepulse set at $-40 \mathrm{mV}$ to inactivate the fast component while leaving $\mathrm{I}_{\mathrm{K}}$ mostly unchanged

145 attributable to its very slow inactivation (see below). The fast $I_{A}$ component was then isolated by

146 subtracting the family of currents obtained with the $-40 \mathrm{mV}$ prepulse from that obtained with the

$147-100 \mathrm{mV}$ prepulse. Activation of $\mathrm{I}_{\mathrm{A}}$ was quantified by measuring the peak current reached during

148 each voltage step in the family (see Analysis section below). Inactivation of $I_{A}$ was estimated

149 from the peak current during the final step to $-10 \mathrm{mV}$ that followed the family of voltage steps. All

150 protocols for $I_{A}$ analysis were leak subtracted using the online -P/8 (average of 8 sweeps, 1/8 
151 the size of the voltage step in the opposite direction, from a baseline potential of $-65 \mathrm{mV}$ )

152 (Bezanilla and Armstrong, 1977).

153 Time course of inactivation of $\mathrm{I}_{\mathrm{A}}$ was characterized by stepping the membrane potential to -100

$154 \mathrm{mV}$ for $500 \mathrm{~ms}$ to remove inactivation, then stepping to the inactivation potential $(-40 \mathrm{mV})$ for 0 ,

$1550.5,1,2,4,8,16,32,64,128,256,512,1024 \mathrm{~ms}$, followed by a test pulse at $-10 \mathrm{mV}$ to assess

156 the peak current. The non-inactivating component during the test pulse after $1024 \mathrm{~ms}$

157 inactivation was subtracted from each of the other traces to isolate the transient current.

158 Similarly, the time course of recovery from inactivation of $\mathrm{I}_{\mathrm{A}}$ was characterized by stepping the

159 membrane potential to $-40 \mathrm{mV}$ for $500 \mathrm{~ms}$ to fully inactivate $\mathrm{I}_{\mathrm{A}}$, and then stepping to $-100 \mathrm{mV}$ for

160 the durations above, followed by a test pulse at $-10 \mathrm{mV}$ to assess the peak current. The non-

161 inactivating component at $0 \mathrm{~ms}$ recovery was subtracted from each of the other traces to isolate

162 the transient current.

163 To study $I_{K}$, a separate set of recordings was required because of the slow inactivation of this

164 component. Indeed full inactivation and recovery required $>10 \mathrm{~s}$ at $+50 \mathrm{mV}$ and $-100 \mathrm{mV}$,

165 respectively. Cells did not remain stable upon repeated exposure to these potentials, thus more

166 moderate potentials were used to permit estimation of these properties within the command

167 potentials and durations the cells tolerated.

Activation and inactivation of $I_{K}$. To quantify activation, a double prepulse protocol was used: an initial prepulse to $-75 \mathrm{mV}$ for $10 \mathrm{~s}$ was used to remove inactivation from $\mathrm{I}_{\mathrm{K}}$, then a second prepulse to $-50 \mathrm{mV}$ for $1 \mathrm{~s}$ was used to inactivate $\mathrm{I}_{\mathrm{A}}$. After these two prepulses, test pulses of 10 $\mathrm{s}$ from -50 to $+50 \mathrm{mV}$ in $10 \mathrm{mV}$ increments were used to measure the peak $I_{\mathrm{k}}$ current. A final step to $+50 \mathrm{mV}$ for $100 \mathrm{~ms}$ was used following each test pulse to measure inactivation of $\mathrm{I}_{\mathrm{K}}$. The long duration voltage steps required to characterize this current makes traditional online leak subtraction unrealistic. For the activation of $I_{k}$, leak currents were subtracted offline using the approach of (Kimm and Bean, 2014). The shape of the leak response was acquired from the average of 16 steps of $-5 \mathrm{mV}$ for $50 \mathrm{~ms}$ from the holding potential of $-65 \mathrm{mV}$. Offline, the average was scaled by the voltage difference and subtracted from the portion of the raw current sweep containing the activation test pulses. The leak steps were run immediately before each voltage-clamp protocol. Prior to each leak acquisition, passive properties were recorded and both slow capacitance and series resistance compensation (50-70\%) adjusted. 
Time course of inactivation of $I_{K}$ was characterized by first removing inactivation by holding at $75 \mathrm{mV}$ for $10 \mathrm{~s}$, then $\mathrm{I}_{\mathrm{A}}$ was inactivated by stepping to $-50 \mathrm{mV}$ for $1 \mathrm{~s}$. This was followed by a variable duration inactivation pulse $(0.1,0.21,0.42,0.83,1.64,3.25,6.46,12.87,25.68,51.29 \mathrm{~s})$ at $-30 \mathrm{mV}$, followed by a test pulse at $+50 \mathrm{mV}$. Because inactivation was incomplete even after $51.29 \mathrm{~s}$ at $-30 \mathrm{mV}$, this remaining current was not subtracted and the inactivation graphs level off at $\sim 30 \%$. Recovery from inactivation for $I_{k}$ was studied using an inactivating prepulse of +50 $\mathrm{mV}$ for $10 \mathrm{~s}$, followed by a variable duration recovery pulse at $-80 \mathrm{mV}(0.01,0.03,0.06,0.11$, $0.2,0.37,0.7,1.35,2.64,5.21,10.34,20.59 \mathrm{~s})$, a brief pulse to inactivate $\mathrm{I}_{\mathrm{A}}(-50 \mathrm{mV}$ for $1 \mathrm{~s})$, and a test pulse at $+50 \mathrm{mV}$ for $100 \mathrm{~ms}$. The peak current was plotted as a function of the recovery prepulse duration. Since inactivation was incomplete, the non-inactivated current was not subtracted (recovery graphs start at $\sim 30 \%$ ).

Analysis Current density was calculated by dividing current by capacitance for each cell. To assess the voltage-dependence of activation, both $I_{A}$ and $I_{K}$ were divided by the driving force derived from the Goldman-Hodgkin-Katz (GHK) current equation (Clay, 2000, 2009). To estimate $V_{0.5 a c t i v a t i o n}, I_{A}$ and $I_{K}$ were divided by the GHK driving force, normalized to the maximum value, plotted as a function of step potential and fit with the Boltzmann equation:

$\mathrm{V}$ is the command potential of the step, $\mathrm{V}_{0.5}$ is the potential at half maximum, and $\mathrm{k}$ is the "slope factor" (k has no units attributable to the F/RT factor). Voltage dependence of inactivation was characterized using the same equation to fit the normalized current measured during the inactivation test pulse.

Action potential properties. To characterize action potential properties, current-clamp recordings were obtained in the presence of antagonists of receptors for fast synaptic transmission $(20 \mu \mathrm{M}$ D-APV, $10 \mu \mathrm{M}$ CNQX, $100 \mu \mathrm{M}$ picrotoxin). Cells were maintained at $-65 \mathrm{mV}$ by current injection $(<50 \mathrm{pA})$ in current-clamp after bridge compensation of series resistance by at least $95 \%$. sweeps) were delivered to test the membrane potential response. The first current step to display an action potential was defined as the rheobase and the first spike analyzed in detail. 
210 exceeded $1 \mathrm{~V} / \mathrm{s}$. Action potential latency was defined as the time from start of the current

211 injection to threshold. Rate of rise was defined as the maximum of the voltage trace derivative

212 from threshold to peak. Full width of the action potential at half maximum (FWHM), and

213 afterhyperpolarization (AHP) time and amplitude were measured relative to threshold.

214 Statistics. Data are reported as mean \pm SEM, with individual values shown where practical.

215 Statistical comparisons were made using Prism 9 (GraphPad Software). Data were tested for

216 normal distribution with Shapiro-Wilk. Tests were chosen appropriate for the experimental

217 design and data distribution as specified in the results. For two-way ANOVA, the Bonferroni post

$218 h o c$ is considered sufficiently robust to use with non-normally distributed data (Underwood,

219 1996). Significance was set at $p<0.05$.

\section{Results}

221 Verification of gonadectomy Short-term gonadectomy had no effect on body mass within either

222 sex (females $\mathrm{n}=12$ sham diestrus $21.4 \pm 0.6 \mathrm{~g}, \mathrm{n}=14$ OVX $21.8 \pm 0.3 \mathrm{~g}$; males $\mathrm{n}=13$ sham $26.1 \pm 0.7$

$223 \mathrm{~g}, \mathrm{n}=13$ ORX 25.4 $\pm 0.6 \mathrm{~g}$, two-way ANOVA gonadal status: $\mathrm{F}(1,48)=0.07108 ; \mathrm{P}=0.7909)$. As

224 expected, males were heavier than females (two-way ANOVA sex: $F(1,48)=53.80 ; P<0.0001$ ).

225 In females, OVX reduced uterine mass (sham diestrus $63.4 \pm 5.0 \mathrm{mg}$, OVX $29.6 \pm 1.3 \mathrm{mg}$,

226 unpaired two-tailed Student's t test: $\mathrm{t}=7.001, \mathrm{df}=24, \mathrm{P}<0.0001)$. In males, $\mathrm{ORX}$ reduced seminal

227 vesicle mass (sham 217.2 $\pm 11.6 \mathrm{mg}$, ORX 56.6 $\pm 4.4 \mathrm{mg}$, unpaired two-tailed Student's t test:

$228 \mathrm{t}=12.97, \mathrm{df}=24, \mathrm{P}<0.0001)$.

229 Passive properties of GnRH neurons do not vary with sex or gonadal status under conditions

230 used to characterize potassium currents Critical to evaluating of current properties among

231 treatments is comparison of similar quality recordings. No difference was observed among

232 groups for uncompensated series resistance (Figure 1A). Nor were any differences in the

233 passive cellular properties of input resistance (Figure 1B), capacitance (Figure 1C) or holding

234 current (Figure 1D) attributable to either sex or gonadal status. These latter measures offer a

235 combined view of recording quality as well as insight into potential biological changes, such as

236 cell size or membrane conductance (two-way ANOVA, Table 1).

237 Neither sex nor gonadal status affect voltage-gated potassium currents of GnRH neurons The 238 output of $\mathrm{GnRH}$ neurons in terms of spontaneous firing pattern and hormone release is 
239 increased by removal of homeostatic gonadal steroid feedback accomplished via gonadectomy.

240 We hypothesized that removing gonadal steroid feedback would reduce voltage-gated

241 potassium currents. Two components of this current were examined, a fast $\mathrm{I}_{\mathrm{A}}$-like current and a

242 slowly-inactivating $I_{K}$-like current. No measured property of either current differed with sex or

243 gonadal status (Figures 2, 3; Tables 3, 4). Only the parameters calculated from the Boltzmann

244 fit, specifically the inactivation $V 0.5$ and slope factor for $I_{A}$ and both inactivation and activation

245 slope factors for $I_{K}$ exhibited weakly significant $P$ values.

246 Passive properties of GnRH neurons do not vary with sex or gonadal status under conditions

247 used to characterize action potentials To record action potential properties, the blockers of

248 voltage-gated calcium and sodium channels needed to isolate potassium currents were omitted;

249 this may alter the passive properties of the cells, thus these parameters are reported separately

250 for the two types of recordings. There was a weak interaction between sex and gonadal status

251 for uncompensated series resistance (Figure 4A, $P=0.0436$ ). This difference is unlikely to

252 account for a difference in measured values as bridge balance was in effect to compensate

253 series resistance by $>95 \%$ during action potential recordings. As was observed for recordings of

254 potassium currents, there were no differences in the passive cellular properties of input

255 resistance (Figure 4B), capacitance (Figure 4C) or holding current (Figure 4D) attributable to

256 either sex or gonadal status.

257 Neither excitability nor first action potential properties are altered by sex or gonadal status.

258 Current-clamp recordings of action potential properties were used to assess possible general

259 differences in the intrinsic properties of $\mathrm{GnRH}$ neurons in the experimental groups (Figure 5).

260 No differences were observed in the firing response to current injection attributable to sex or

261 gonadal status (three-way repeated-measures ANOVA, Table 5). Post-analysis consolidation of

262 these data to examine effects of either sex or gonadal status by two-way repeated measures

263 ANOVA revealed a mild interaction between sex and current injection, but no post hoc

264 significance (Bonferroni); there was no effect of gonadectomy. There were also no differences

265 observed in any action potential property examined (two-way ANOVA, Table 6). Together these

266 observations suggest that homeostatic feedback does not induce major changes in action

267 potentials of $\mathrm{GnRH}$ neurons. 


\section{Discussion}

270 A century ago, early studies of pituitary ablation and replacement revealed a link between the

271 emerging science of neuroendocrinology and reproductive processes (Evans HM, 1921; Smith,

272 1927). Around the same time, the reverse link was being made by observing the effects of

273 orchidectomy upon the pituitary, and amelioration of these effects by replacement with fat-

274 soluble extracts of the testes (McCullagh, 1932). It is now well established that reproduction

275 revolves around the stimulatory and feedback interactions of the hypothalamo-pituitary-gonadal

276 axis, with $\mathrm{GnRH}$ neurons serving as the final common pathway for central signaling to the

277 pituitary. These interactions are homeostatic in males and homeostatic throughout most of the

278 reproductive cycle in females; removal of the gonads opens these homeostatic feedback loops

279 and results in increased $\mathrm{GnRH}$ neuron activity, $\mathrm{GnRH}$ release and $\mathrm{LH}$ release in both sexes

280 (Leipheimer et al., 1985; Levine et al., 1985; Karsch et al., 1987; Caraty and Locatelli, 1988;

281 Condon et al., 1988; Jackson and Kuehl, 2000; Han et al., 2020). Despite the similarity in

282 steady-state endocrine response, it is possible that latent sex differences in underlying

283 neurobiological mechanisms exist (Jain et al., 2019). We tested the hypotheses that removal of

284 negative homeostatic feedback would reduce potassium currents and increase the excitability of

$285 \mathrm{GnRH}$ neurons. Based on the parameters we quantified, no substantial differences were

286 observed that could be attributed to sex or feedback condition. We thus reject these hypotheses.

287 The present data showing no changes in the intrinsic properties of GnRH neurons in females

288 between diestrous and OVX mice support prior work assessing excitability of GnRH neurons in

289 OVX vs OVX+E mice exhibiting diurnal changes between negative and positive feedback

290 (Christian et al., 2005). In this model, GnRH neuron activity and LH release are suppressed in

291 the morning (AM) in OVX+E mice relative to OVX mice, demonstrating homeostatic negative

292 feedback, but increased in the afternoon (PM) in cells from OVX+E mice, demonstrating

293 estradiol positive feedback. Interestingly there were no differences in GnRH neuron excitability

294 between OVX mice at either time of day and OVX+E mice in the AM (negative feedback),

295 whereas $\mathrm{GnRH}$ neurons from OVX+E mice recorded in the PM during positive feedback were

296 more excitable (Adams et al., 2018b). The present work extends these data to include both a

297 comparison between the sexes and a comparison using the open loop OVX/ORX condition vs

298 sham-operated controls to ameliorate caveats associated with steroid hormone replacement.

299 The lack of effect of removing homeostatic feedback suggests a majority of the changes that

300 lead to increased $\mathrm{GnRH}$ output in gonadectomized animals are processed presynaptic to these

301 cells. In and of itself, this concept is not new as $\mathrm{GnRH}$ neurons do not appear to express 
detectable levels of steroid hormone receptors other than the beta isoform of the estradiol receptor (Herbison et al., 1996; Hrabovszky et al., 2000; Hrabovszky et al., 2007). There has thus long been a relative consensus in the field that steroid feedback is integrated via upstream, steroid-responsive cells (Wintermantel et al., 2006). The lack of observed changes in $\mathrm{GnRH}$ neuron properties examined suggests homeostatic negative feedback signals are conveyed from these afferents in a manner that alters the output of $\mathrm{GnRH}$ neurons without substantial biophysical changes at the level of the cell soma. Of note, there is increased frequency of $\mathrm{GABA}_{A}$-receptor-mediated postsynaptic currents, which can excite $\mathrm{GnRH}$ neurons (DeFazio et al., 2002; Herbison and Moenter, 2011), observed in GnRH neurons from ORX vs intact males (Chen and Moenter, 2009), and in cells from OVX vs OVX+E females during negative feedback (Christian and Moenter, 2007). Postsynaptic currents have relatively short-lived effects on membrane potential that may not lead to changes in overall excitability. Interestingly, changing homeostatic negative feedback does engage mechanisms affecting excitability in arcuate kisspeptin neurons, also known as KNDY neurons for their coexpression of three neuropeptides: kisspeptin, neurokinin B and dynorphin (Oakley et al., 2009; Moore et al., 2018). KNDy neurons have been postulated to be key afferent inputs to $\mathrm{GnRH}$ neurons to drive episodic release from these cells (Qiu et al., 2016; Clarkson et al., 2017; Vanacker et al., 2017). In KNDy neurons from OVX+E vs OVX females examined during negative feedback in the morning, estradiol reduced fast transient $I_{A}$ (DeFazio et al., 2019), and $I_{A}$ modifies action potential patterns in these cells (Mendonca et al., 2018).

The lack of changes in the homeostatic vs open loop models studied in the present work stand in marked contrast to changes that occur in $\mathrm{GnRH}$ neurons from females during estradiol positive feedback (Adams et al., 2018a; Adams et al., 2018b; Adams et al., 2019). In addition to the increase in $\mathrm{GnRH}$ neuron excitability observed during positive feedback mentioned above, $\mathrm{GnRH}$ neurons exhibit reduced transient potassium currents and increased high-voltageactivated calcium conductances in OVX+E mice during positive feedback (DeFazio and Moenter, 2002; Sun et al., 2010). While both the removal of negative feedback by gonadectomy and induction of positive feedback both increase $\mathrm{GnRH}$ release, the nature of this increase is quite different. Removal of negative feedback maintains the episodic $\mathrm{GnRH} / \mathrm{LH}$ release pattern that is characteristic in males and most of the reproductive cycle in females (Leipheimer et al., 1985;

332 Levine et al., 1985; Karsch et al., 1987; Caraty and Locatelli, 1988; Condon et al., 1988;

333 Jackson and Kuehl, 2000; Han et al., 2020). Pulse frequency and amplitude are typically

334 increased. Even in long-term castrated rams, when the pulsatile nature of LH release is no 
335 longer evident, high frequency GnRH pulses are clearly observed (Caraty and Locatelli, 1988).

336 Induction of positive feedback, however, shifts the pattern from episodic to a continual elevation

337 above baseline that lasts for several hours (Sarkar et al., 1976; Levine and Ramirez, 1982;

338 Clarke et al., 1987; Moenter et al., 1990; Moenter et al., 1991; Moenter et al., 1992a; Moenter et

339 al., 1992b; Xia et al., 1992). Given the fundamental differences in how the output of $\mathrm{GnRH}$

340 neurons is altered in these two circumstances, it is reasonable to postulate that more extensive

341 changes are required for successful positive feedback, and that this is in part accomplished by

342 extending the mechanisms engaged to the alteration of $\mathrm{GnRH}$ neuron intrinsic properties to

343 allow continuous secretion to be maintained. Conceptually, pulse frequency can be rapidly

344 modulated by homeostatic perturbances that influence reproduction. For example, inflammatory

345 stress (Battaglia et al., 1998), hypoglycemia (Chen et al., 1996), and naloxone antagonism of

346 opiates (Caraty et al., 1987) all rapidly induce changes in the pulse pattern of GnRH or multiunit

347 activity associated with LH in the hypothalamus. In contrast, estradiol induction of positive

348 feedback is a process with a substantial (typically $>12 \mathrm{~h}$ ) delay to the increased release and this

349 increase appears to be all or none as it is not dependent upon continued presence of estradiol

350 (Evans et al., 1997).

351 The apparently different postsynaptic effects of removing negative feedback and inducing

352 positive feedback raise some interesting questions for future contemplation. This is particularly

353 true given that the prevailing view in the field is that the neuromodulator kisspeptin plays an

354 important role in activating both episodic and surge modes of GnRH release (Porteous and

355 Herbison, 2019; Wang et al., 2019). Kisspeptin application in brain slices reduces $I_{A}$ in a manner

356 similar to induction of estradiol positive feedback (Pielecka-Fortuna et al., 2011), and also

357 increases excitability of $\mathrm{GnRH}$ neurons (Adams et al., 2018b), indicating it can alter the intrinsic

358 properties of these cells. The two hypothalamic populations of kisspeptin neurons, the

359 aforementioned KNDy neurons in the arcuate and those in the anteroventral periventricular area

360 (AVPV) are thought to mediate pulsatile and surge modes of $\mathrm{GnRH}$ release, respectively. These

361 populations possess different cotransmitters and mediators (Cravo et al., 2011; Skrapits et al.,

362 2015); if co-released with kisspeptin these could produce counteracting effects in the

363 postsynaptic GnRH neuron. Alternatively other afferent populations may have critical roles. In

364 this regard, the increase in $\mathrm{GnRH}$ neuron firing induced by kisspeptin application is longer in

365 duration than the typical pulse (Moenter et al., 1992b; Evans et al., 1996; Han et al., 2005;

366 Pielecka-Fortuna et al., 2008). The neuromodulator known as gonadotropin-inhibitory hormone

367 in birds and RFRP3 in mammals can counteract the activating effects of applied kisspeptin on 
GnRH neuron firing rate in brain slices by activating a potassium current (Wu et al., 2009). While speculative, an interplay of kisspeptin and RFRP3 may have opposing effects on intrinsic GnRH properties.

371 While we have confidence in the lack of effect of sex or removing homeostatic feedback on the

372 properties examined in the present work, it is important to acknowledge alternative possibilities

373 and mechanisms. It is possible that removing negative feedback induces equal and opposite

374 changes in intrinsic properties resulting in masking of these changes in the current-clamp

375 recordings. This seems unlikely given the different kinetic properties of the voltage-gated

376 channels likely to mediate changes in action potential firing and properties. It is also possible

377 that changes are induced in the biophysical properties of $\mathrm{GnRH}$ neurons that are distal to the

378 soma and not possible to monitor in our brain slice preparation. For example, arcuate kisspeptin

379 neurons can interact with GnRH neurons via kisspeptin and neurokinin B at the level of the

380 terminals in the median eminence (Gaskins et al., 2013; Glanowska and Moenter, 2015; Yip et

381 al., 2015). Examining these properties at a different point post gonadectomy may have revealed

382 sex differences. While both males and females increase $\mathrm{GnRH}$ and $\mathrm{LH}$ release following

383 gonadectomy, the increase is somewhat delayed in females. At the time point we investigated of

384 5-7 days post gonadectomy, clear increases in LH have occurred in both sexes (Yamamoto et

385 al., 1970). It is also possible that removing homeostatic feedback alters other aspects of $\mathrm{GnRH}$

386 neurons to increase GnRH output, such as increasing GnRH mRNA (Finn et al., 1998; Gore,

387 1998), altering ionotropic receptors that produce brief changes in membrane potential, or

388 changing excitation secretion coupling to make it more effective. Any of these alternative

389 mechanisms could be sexually differentiated.

390 In sum, the present work rejected the hypotheses that removing homeostatic gonadal feedback

391 induces changes in potassium currents and excitability of $\mathrm{GnRH}$ neurons. In so doing, we

392 provide evidence for different mechanistic strategies to regulate the output of GnRH neurons

393 during homeostatic vs positive feedback. 


\section{References}

Adams C, Chen X, Moenter SM (2018a) Changes in GABAergic transmission to and intrinsic excitability of gonadotropin-releasing hormone $(\mathrm{GnRH})$ neurons during the estrous cycle in mice. eNeuro 5:e0171-0118.

Adams C, Stroberg W, DeFazio RA, Schnell S, Moenter SM (2018b) Gonadotropin-releasing hormone $(\mathrm{GnRH})$ neuron excitability is regulated by estradiol feedback and kisspeptin. J Neurosci 38:1249-1263.

Adams C, DeFazio RA, Christian CA, Milescu LS, Schnell S, Moenter SM (2019) Changes in both neuron intrinsic properties and neurotransmission are needed to drive the increase in GNRH neuron firing rate during estradiol-positive feedback. J Neurosci 39:2091-2101.

Bakirtzis C, Konstantinopoulou E, Langdon DW, Grigoriadou E, Minti F, Nikolaidis I, Boziki MK, Tatsi T, loannidis P, Karapanayiotides T, Afrantou T, Hadjigeorgiou G, Grigoriadis N (2018) Long-term effects of prolonged-release fampridine in cognitive function, fatigue, mood and quality of life of ms patients: The IGNITE study. J Neurol Sci 395:106-112.

Barry PH (1994) JPCalc, a software package for calculating liquid junction potential corrections in patch-clamp, intracellular, epithelial and bilayer measurements and for correcting junction potential measurements. J Neurosci Meth 51:107-116.

Battaglia DF, Brown ME, Krasa HB, Thrun LA, Viguie C, Karsch FJ (1998) Systemic challenge with endotoxin stimulates corticotropin-releasing hormone and arginine vasopressin secretion into hypophyseal portal blood: Coincidence with gonadotropin-releasing hormone suppression. Endocrinology 139:4175-4181.

Bezanilla F, Armstrong CM (1977) Inactivation of the sodium channel. I. Sodium current experiments. J Gen Physiol 70:549-566.

Caraty A, Locatelli A (1988) Effect of time after castration on secretion of Ihrh and lh in the ram. J Reprod Fertil 82:263-269.

Caraty A, Locatelli A, Schanbacher B (1987) [augmentation, by naloxone, of the frequency and amplitude of lh-rh pulses in hypothalamo-hypophyseal portal blood in the castrated ram]. C R Acad Sci III 305:369-374.

Chen MD, Ordog T, O'Byrne KT, Goldsmith JR, Connaughton MA, Knobil E (1996) The insulin hypoglycemia-induced inhibition of gonadotropin-releasing hormone pulse generator activity in the rhesus monkey: Roles of vasopressin and corticotropin-releasing factor. Endocrinology 137:2012-2021.

Chen P, Moenter SM (2009) GABAergic transmission to gonadotropin-releasing hormone $(\mathrm{GnRH})$ neurons is regulated by $\mathrm{GnRH}$ in a concentration-dependent manner engaging multiple signaling pathways. J Neurosci 29:9809-9818.

Christian CA, Moenter SM (2007) Estradiol induces diurnal shifts in GABA transmission to gonadotropin-releasing hormone neurons to provide a neural signal for ovulation. $J$ Neurosci 27:1913-1921.

Christian CA, Moenter SM (2010) The neurobiology of preovulatory and estradiol-induced gonadotropin-releasing hormone surges. Endocrine reviews 31:544-577.

Christian CA, Mobley JL, Moenter SM (2005) Diurnal and estradiol-dependent changes in gonadotropin-releasing hormone neuron firing activity. Proc Natl Acad Sci U S A 102:15682-15687.

Clarke IJ, Thomas GB, Yao B, Cummins JT (1987) GnRH secretion throughout the ovine estrous cycle. Neuroendocrinology 46:82-88.

Clarkson J, Han SY, Piet R, McLennan T, Kane GM, Ng J, Porteous RW, Kim JS, Colledge WH, Iremonger KJ, Herbison AE (2017) Definition of the hypothalamic GnRH pulse generator in mice. Proc Natl Acad Sci U S A 114:E10216-E10223.

Clay JR (2000) Determining K+ channel activation curves from K+ channel currents. European biophysics journal : EBJ 29:555-557. 
Clay JR (2009) Determining K channel activation curves from K channel currents often requires the goldman-hodgkin-katz equation. Frontiers in Cellular Neuroscience 3:20.

Condon TP, Dykshoorn-Bosch MA, Kelly MJ (1988) Episodic luteinizing-hormone release in the ovariectomized female guinea pig: Rapid inhibition by estrogen. Biol Reprod 38:121-126.

Cravo RM, Margatho LO, Osborne-Lawrence S, Donato J, Jr., Atkin S, Bookout AL, Rovinsky S, Frazao R, Lee CE, Gautron L, Zigman JM, Elias CF (2011) Characterization of kiss1 neurons using transgenic mouse models. Neuroscience 173:37-56.

Czieselsky K, Prescott M, Porteous R, Campos P, Clarkson J, Steyn FJ, Campbell RE, Herbison AE (2016) Pulse and surge profiles of luteinizing hormone secretion in the mouse. Endocrinology 157:4794-4802.

DeFazio RA, Moenter SM (2002) Estradiol feedback alters potassium currents and firing properties of gonadotropin-releasing hormone neurons. Mol Endocrinol 16:2255-2265.

DeFazio RA, Heger S, Ojeda SR, Moenter SM (2002) Activation of a-type gamma-aminobutyric acid receptors excites gonadotropin-releasing hormone neurons. Mol Endocrinol 16:2872-2891.

DeFazio RA, Navarro MA, Adams CE, Milescu LS, Moenter SM (2019) Estradiol enhances the depolarizing response to GABA and AMPA synaptic conductances in arcuate kisspeptin neurons by diminishing voltage-gated potassium currents. J Neurosci 39:9532-9545.

Docke F, Dorner G (1965) The mechanism of the induction of ovulation by oestrogens. J Endocrinol 33:491-499.

Dror T, Franks J, Kauffman AS (2013) Analysis of multiple positive feedback paradigms demonstrates a complete absence of $\mathrm{Ih}$ surges and $\mathrm{GnRH}$ activation in mice lacking kisspeptin signaling. Biol Reprod 88:146.

Evans HM LJ (1921) The effect of the anterior lobe administered intraperitoneally upon growth, maturity, and oestrus cycles of the rat. Anat Rec 21:62-63.

Evans NP, Dahl GE, Padmanabhan V, Thrun LA, Karsch FJ (1997) Estradiol requirements for induction and maintenance of the gonadotropin-releasing hormone surge: Implications for neuroendocrine processing of the estradiol signal. Endocrinology 138:5408-5414.

Evans NP, Dahl GE, Caraty A, Padmanabhan V, Thrun LA, Karsch FJ (1996) How much of the gonadotropin-releasing hormone $(\mathrm{GnRH})$ surge is required for generation of the luteinizing hormone surge in the ewe? Duration of the endogenous $\mathrm{GnRH}$ signal. Endocrinology 137:4730-4737.

Finn PD, Steiner RA, Clifton DK (1998) Temporal patterns of gonadotropin-releasing hormone $(\mathrm{GnRH}), \mathrm{c}-\mathrm{fos}$, and galanin gene expression in $\mathrm{GnRH}$ neurons relative to the luteinizing hormone surge in the rat. J Neurosci 18:713-719.

Fisher CR, Graves KH, Parlow AF, Simpson ER (1998) Characterization of mice deficient in aromatase (ARKO) because of targeted disruption of the cyp19 gene. Proc Natl Acad Sci U S A 95:6965-6970.

Gaskins GT, Glanowska KM, Moenter SM (2013) Activation of neurokinin 3 receptors stimulates $\mathrm{GnRH}$ release in a location-dependent but kisspeptin-independent manner in adult mice. Endocrinology 154:3984-3989.

Glanowska KM, Moenter SM (2015) Differential regulation of GnRH secretion in the preoptic area (POA) and the median eminence (ME) in male mice. Endocrinology 156:231-241.

Gore AC (1998) Diurnal rhythmicity of gonadotropin-releasing hormone gene expression in the rat. Neuroendocrinology 68:257-263.

Han SK, Gottsch ML, Lee KJ, Popa SM, Smith JT, Jakawich SK, Clifton DK, Steiner RA, Herbison AE (2005) Activation of gonadotropin-releasing hormone neurons by kisspeptin as a neuroendocrine switch for the onset of puberty. J Neurosci 25:11349-11356.

Han SY, Cheong I, McLennan T, Herbison AE (2020) Neural determinants of pulsatile luteinizing hormone secretion in male mice. Endocrinology 161:1-10. 
Herbison AE, Moenter SM (2011) Depolarising and hyperpolarising actions of GABA(A) receptor activation on gonadotrophin-releasing hormone neurones: Towards an emerging consensus. J Neuroendocrinol 23:557-569.

Herbison AE, Skinner DC, Robinson JE, King IS (1996) Androgen receptor-immunoreactive cells in ram hypothalamus: Distribution and co-localization patterns with gonadotropinreleasing hormone, somatostatin and tyrosine hydroxylase. Neuroendocrinology 63:120131.

Hoffman DA (2013) K+ channel regulation of multicompartmental signal integration. Neuron 79:403-405.

Hrabovszky E, Kallo I, Szlavik N, Keller E, Merchenthaler I, Liposits Z (2007) Gonadotropinreleasing hormone neurons express estrogen receptor-beta. J Clin Endocrinol Metab 92:2827-2830.

Hrabovszky E, Shughrue PJ, Merchenthaler I, Hajszan T, Carpenter CD, Liposits Z, Petersen SL (2000) Detection of estrogen receptor-beta messenger ribonucleic acid and 125iestrogen binding sites in luteinizing hormone-releasing hormone neurons of the rat brain. Endocrinology 141:3506-3509.

Jackson GL, Kuehl DE (2000) Interactions of photoperiod, testosterone, and naloxone on GnRH and Ih pulse parameters in the male sheep. Domest Anim Endocrinol 18:97-110.

Jain A, Huang GZ, Woolley CS (2019) Latent sex differences in molecular signaling that underlies excitatory synaptic potentiation in the hippocampus. J Neurosci 39:1552-1565.

Johnston J, Forsythe ID, Kopp-Scheinpflug C (2010) Going native: Voltage-gated potassium channels controlling neuronal excitability. J Physiol 588:3187-3200.

Karsch FJ, Cummins JT, Thomas GB, Clarke IJ (1987) Steroid feedback inhibition of pulsatile secretion of gonadotropin-releasing hormone in the ewe. Biol Reprod 36:1207-1218.

Kimm T, Bean BP (2014) Inhibition of A-type potassium current by the peptide toxin SNX-482. J Neurosci 34:9182-9189.

Leipheimer RE, Bona-Gallo A, Gallo RV (1985) Ovarian steroid regulation of pulsatile luteinizing hormone release during the interval between the mornings of diestrus 2 and proestrus in the rat. Neuroendocrinology 41:252-257.

Levine JE, Ramirez VD (1982) Luteinizing hormone-releasing hormone release during the rat estrous cycle and after ovariectomy, as estimated with push-pull cannulae. Endocrinology 111:1439-1448.

Levine JE, Duffy MT (1988) Simultaneous measurement of luteinizing hormone (LH)-releasing hormone, Ih, and follicle-stimulating hormone release in intact and short-term castrate rats. Endocrinology 122:2211-2221.

Levine JE, Norman RL, Gliessman PM, Oyama TT, Bangsberg DR, Spies HG (1985) In vivo gonadotropin-releasing hormone release and serum luteinizing hormone measurements in ovariectomized, estrogen-treated rhesus macaques. Endocrinology 117:711-721.

Liu X, Porteous R, Herbison AE (2017) Dynamics of GnRH neuron ionotropic GABA and glutamate synaptic receptors are unchanged during estrogen positive and negative feedback in female mice. eNeuro 4:e0259-0217.

McCullagh DR (1932) Dual endocrine activity of the testes. Science 76:19-20.

Mendonca PRF, Kyle V, Yeo SH, Colledge WH, Robinson HPC (2018) Kv4.2 channel activity controls intrinsic firing dynamics of arcuate kisspeptin neurons. J Physiol 596:885-899.

Moenter SM, Caraty A, Karsch FJ (1990) The estradiol-induced surge of gonadotropin-releasing hormone in the ewe. Endocrinology 127:1375-1384.

Moenter SM, Brand RC, Karsch FJ (1992a) Dynamics of gonadotropin-releasing hormone $(\mathrm{GnRH})$ secretion during the $\mathrm{GnRH}$ surge: Insights into the mechanism of $\mathrm{GnRH}$ surge induction. Endocrinology 130:2978-2984. 
Moenter SM, Caraty A, Locatelli A, Karsch FJ (1991) Pattern of gonadotropin-releasing hormone $(\mathrm{GnRH})$ secretion leading up to ovulation in the ewe: Existence of a preovulatory GnRH surge. Endocrinology 129:1175-1182.

Moenter SM, Brand RM, Midgley AR, Karsch FJ (1992b) Dynamics of gonadotropin-releasing hormone release during a pulse. Endocrinology 130:503-510.

Moore AM, Coolen LM, Porter DT, Goodman RL, Lehman MN (2018) KNDY cells revisited. Endocrinology 159:3219-3234.

Oakley AE, Clifton DK, Steiner RA (2009) Kisspeptin signaling in the brain. Endocrine reviews 30:713-743.

Peikert K, Naumann M, Gunther R, Wegner F, Hermann A (2019) Off-label treatment of 4 amyotrophic lateral sclerosis patients with 4-aminopyridine. J Clin Pharmacol 59:14001404.

Pielecka J, Moenter SM (2006) Effect of steroid milieu on gonadotropin-releasing hormone-1 neuron firing pattern and luteinizing hormone levels in male mice. Biol Reprod 74:931937.

Pielecka J, Quaynor SD, Moenter SM (2006) Androgens increase gonadotropin-releasing hormone neuron firing activity in females and interfere with progesterone negative feedback. Endocrinology 147:1474-1479.

Pielecka-Fortuna J, Chu Z, Moenter SM (2008) Kisspeptin acts directly and indirectly to increase gonadotropin-releasing hormone neuron activity and its effects are modulated by estradiol. Endocrinology 149:1979-1986.

Pielecka-Fortuna J, DeFazio RA, Moenter SM (2011) Voltage-gated potassium currents are targets of diurnal changes in estradiol feedback regulation and kisspeptin action on gonadotropin-releasing hormone neurons in mice. Biol Reprod 85:987-995.

Plant TM (1982) Effects of orchidectomy and testosterone replacement treatment on pulsatile luteinizing hormone secretion in the adult rhesus monkey (macaca mulatta). Endocrinology 110:1905-1913.

Porteous R, Herbison AE (2019) Genetic deletion of esr1 in the mouse preoptic area disrupts the LH surge and estrous cyclicity. Endocrinology 160:1821-1829.

Qiu J, Nestor CC, Zhang C, Padilla SL, Palmiter RD, Kelly MJ, Ronnekleiv OK (2016) Highfrequency stimulation-induced peptide release synchronizes arcuate kisspeptin neurons and excites $\mathrm{GnRH}$ neurons. eLife 5:e16246.

Sarkar DK, Chiappa SA, Fink G, Sherwood NM (1976) Gonadotropin-releasing hormone surge in pro-oestrous rats. Nature 264:461-463.

Sharma TP, Blache D, Blackberry MA, Martin GB (1999) Role of peripheral and central aromatization in the control of gonadotrophin secretion in the male sheep. Reprod Fertil Dev 11:293-302.

Silveira MA, Burger LL, DeFazio RA, Wagenmaker ER, Moenter SM (2017) GnRH neuron activity and pituitary response in estradiol-induced vs proestrous luteinizing hormone surges in female mice. Endocrinology 158:356-366.

Skrapits K, Borsay BA, Herczeg L, Ciofi P, Liposits Z, Hrabovszky E (2015) Neuropeptide coexpression in hypothalamic kisspeptin neurons of laboratory animals and the human. Front Neurosci 9:29.

Smith PE (1927) The disabilities caused by hypophysectomy and their repairthe tuberal (hypothalamic) syndrome in the rat. JAMA 88:158-161.

Sun J, Chu Z, Moenter SM (2010) Diurnal in vivo and rapid in vitro effects of estradiol on voltage-gated calcium channels in gonadotropin-releasing hormone neurons. J Neurosci 30:3912-3923.

Tilbrook AJ, de Kretser DM, Clarke IJ (1999) Seasonal changes in the negative feedback regulation of the secretion of the gonadotrophins by testosterone and inhibin in rams. $J$ Endocrinol 160:155-167. 
Underwood AJ (1996) Experiments in ecology: Their logical design and interpretation using analysis of variance: Cambridge University Press.

Vanacker C, Moya MR, DeFazio RA, Johnson ML, Moenter SM (2017) Long-term recordings of arcuate nucleus kisspeptin neurons reveal patterned activity that is modulated by gonadal steroids in male mice. Endocrinology 158:3553-3564.

Wagner EJ, Ronnekleiv OK, Bosch MA, Kelly MJ (2001) Estrogen biphasically modifies hypothalamic GABAergic function concomitantly with negative and positive control of luteinizing hormone release. J Neurosci 21:2085-2093.

Wang L, Vanacker C, Burger LL, Barnes T, Shah YM, Myers MG, Moenter SM (2019) Genetic dissection of the different roles of hypothalamic kisspeptin neurons in regulating female reproduction. eLife 8:e43999.

Wintermantel TM, Campbell RE, Porteous R, Bock D, Grone HJ, Todman MG, Korach KS, Greiner E, Perez CA, Schutz G, Herbison AE (2006) Definition of estrogen receptor pathway critical for estrogen positive feedback to gonadotropin-releasing hormone neurons and fertility. Neuron 52:271-280.

Wu M, Dumalska I, Morozova E, van den Pol AN, Alreja M (2009) Gonadotropin inhibitory hormone inhibits basal forebrain vglut2-gonadotropin-releasing hormone neurons via a direct postsynaptic mechanism. J Physiol 587:1401-1411.

Xia L, Van Vugt D, Alston EJ, Luckhaus J, Ferin M (1992) A surge of gonadotropin-releasing hormone accompanies the estradiol-induced gonadotropin surge in the rhesus monkey. Endocrinology 131:2812-2820.

Yamamoto M, Diebel ND, Bogdanove EM (1970) Analysis of initial and delayed effects of orchidectomy and ovariectomy on pituitary and serum Ih levels in adult and immature rats. Endocrinology 86:1102-1111.

Yip SH, Boehm U, Herbison AE, Campbell RE (2015) Conditional viral tract tracing delineates the projections of the distinct kisspeptin neuron populations to gonadotropin-releasing hormone $(\mathrm{GnRH})$ neurons in the mouse. Endocrinology 156:2582-2594. 


\section{Tables}

Table 1 Statistical parameters from two-way ANOVA for passive properties from potassium current recordings (Figure 1)

\begin{tabular}{|l|l|l|l|}
\hline Property & Sex & Gonadal Status & Interaction \\
\hline & $\mathrm{F}(1,56)=1.512 ;$ & $\mathrm{F}(1,56)=3.308 ;$ & $\mathrm{F}(1,56)=0.1171 ;$ \\
Series resistance & $\mathrm{P}=0.2240$ & $\mathrm{P}=0.0743$ & $\mathrm{P}=0.7335$ \\
\hline & $\mathrm{F}(1,56)=0.03673 ;$ & $\mathrm{F}(1,56)=0.3186 ;$ & $\mathrm{F}(1,56)=0.4542 ;$ \\
Input resistance & $\mathrm{P}=0.8487$ & $\mathrm{P}=0.5747$ & $\mathrm{P}=0.5031$ \\
\hline & $\mathrm{F}(1,56)=0.1963 ;$ & $\mathrm{F}(1,56)=2.540 ;$ & $\mathrm{F}(1,56)=0.08991 ;$ \\
Capacitance & $\mathrm{P}=0.6594$ & $\mathrm{P}=0.1166$ & $\mathrm{P}=0.7654$ \\
\hline & $\mathrm{F}(1,56)=2.592 ;$ & $\mathrm{F}(1,56)=0.6304 ;$ & $\mathrm{F}(1,56)=1.496 ;$ \\
Holding current & $\mathrm{P}=0.1130$ & $\mathrm{P}=0.4306$ & $\mathrm{P}=0.2263$ \\
\hline
\end{tabular}

Table 2. Two-way ANOVA statistical parameters for $\mathrm{I}_{\mathrm{A}}$. Bold indicates $\mathrm{P}<0.05$.

\begin{tabular}{|l|l|l|l|}
\hline Property & Sex & Gonadal Status & Interaction \\
\hline & $\mathrm{F}(1,31)=2.921 ;$ & $\mathrm{F}(1,31)=2.361 ;$ & $\mathrm{F}(1,31)=0.1956 ;$ \\
V0.5 activation & $\mathrm{P}=0.0974$ & $\mathrm{P}=0.1345$ & $\mathrm{P}=0.6614$ \\
\hline V0.5 & $\mathrm{F}(\mathbf{1}, \mathbf{3 1})=\mathbf{4 . 4 7 3} ;$ & $\mathrm{F}(1,31)=0.4313 ;$ & $\mathrm{F}(1,31)=0.008208 ;$ \\
inactivation & $\mathrm{P}=\mathbf{0 . 0 4 2 6}$ & $\mathrm{P}=0.5162$ & $\mathrm{P}=0.9284$ \\
\hline activation & $\mathrm{F}(1,31)=0.004146 ;$ & $\mathrm{F}(1,31)=0.01815 ;$ & $\mathrm{F}(1,31)=0.02354 ;$ \\
slope factor & $\mathrm{P}=0.9491$ & $\mathrm{P}=0.8937$ & $\mathrm{P}=0.8791$ \\
\hline inactivation & $\mathrm{F}(1,31)=0.02076 ;$ & $\mathrm{F}(1,31)=0.07103 ;$ & $\mathrm{F}(\mathbf{1}, \mathbf{3 1})=\mathbf{6 . 8 7 2} ;$ \\
slope factor & $\mathrm{P}=0.8864$ & $\mathrm{P}=0.7916$ & $\mathrm{P}=\mathbf{0 . 0 1 3 4}$ \\
\hline & $\mathrm{F}(1,31)=0.5863 ;$ & $\mathrm{F}(1,31)=0.9055 ;$ & $\mathrm{F}(1,31)=0.02845 ;$ \\
Imax & $\mathrm{P}=0.4496$ & $\mathrm{P}=0.3487$ & $\mathrm{P}=0.8671$ \\
\hline & $\mathrm{F}(1,31)=1.576 ;$ & $\mathrm{F}(1,31)=0.1613 ;$ & $\mathrm{F}(1,31)=0.006205 ;$ \\
Imax density & $\mathrm{P}=0.2188$ & $\mathrm{P}=0.6907$ & $\mathrm{P}=0.9377$ \\
\hline
\end{tabular}

Table 3. Two-way ANOVA statistical parameters for $I_{k}$. Bold indicates $P<0.05$.

\begin{tabular}{|c|c|c|c|}
\hline Property & Sex & Gonadal Status & Interaction \\
\hline V0.5 activation & $\begin{array}{l}F(1,30)=0.09013 \\
P=0.7661\end{array}$ & $\begin{array}{l}F(1,30)= \\
0.0003841 \\
P=0.9845\end{array}$ & $\begin{array}{l}F(1,30)=0.006304 \\
P=0.9372\end{array}$ \\
\hline V0.5 inactivation & $\begin{array}{l}F(1,30)=0.006266 \\
P=0.9374\end{array}$ & $\begin{array}{l}F(1,30)=1.247 \\
P=0.2731\end{array}$ & $\begin{array}{l}F(1,30)=0.1239 \\
P=0.7273\end{array}$ \\
\hline activation slope factor & $\begin{array}{l}F(1,30)=4.294 \\
P=0.0469\end{array}$ & $\begin{array}{l}F(1,30)=1.170 \\
P=0.2880\end{array}$ & $\begin{array}{l}F(1,30)=2.197 \\
P=0.1487\end{array}$ \\
\hline inactivation slope factor & $\begin{array}{l}F(1,30)=3.971 \\
P=0.0554\end{array}$ & $\begin{array}{l}F(1,30)=7.378 \\
P=0.0109\end{array}$ & $\begin{array}{l}F(1,30)=3.864 \\
P=0.0587\end{array}$ \\
\hline (1) & $\begin{array}{l}F(1,30)=0.2979 \\
P=0.5892\end{array}$ & $\begin{array}{l}F(1,30)=1.019 ; \\
P=0.3208\end{array}$ & $\begin{array}{l}F(1,30)=2.259 \\
P=0.1433\end{array}$ \\
\hline Imax density & $\begin{array}{l}F(1,30)=0.4582 \\
P=0.5036\end{array}$ & $\begin{array}{l}F(1,30)=1.725 \\
P=0.1990\end{array}$ & $\begin{array}{l}F(1,30)=2.988 \\
P=0.0942\end{array}$ \\
\hline
\end{tabular}


Table 4 Two-way ANOVA statistical parameters for passive properties from action potential recordings (Figure 5). Bold indicates $\mathrm{P}<0.05$.

\begin{tabular}{|l|l|l|l|}
\hline Property & Sex & Gonadal status & Interaction \\
\hline Series resistance & $\mathrm{F}(1,37)=0.004601 ;$ & $\mathrm{F}(1,37)=0.3899 ;$ & $\mathrm{F}(\mathbf{1}, \mathbf{3 7}) \mathbf{4 . 3 6 6 ;}$ \\
\hline & $\mathrm{P}=0.9463$ & $\mathrm{P}=0.5362$ & $\mathbf{P}=\mathbf{0 4 3 6}$ \\
\hline & $\mathrm{F}(1,37)=0.03866 ;$ & $\mathrm{F}(1,37)=0.1832 ;$ & $\mathrm{F}(1,37)=0.4448 ;$ \\
Input resistance & $\mathrm{P}=0.8452$ & $\mathrm{P}=0.6712$ & $\mathrm{P}=0.5089$ \\
\hline & $\mathrm{F}(1,37)=0.1299 ;$ & $\mathrm{F}(1,37)=1.521 ;$ & $\mathrm{F}(1,37)=1.343 ;$ \\
Holding current & $\mathrm{P}=0.7205$ & $\mathrm{P}=0.2253$ & $\mathrm{P}=0.2539$ \\
\hline
\end{tabular}

Table 5. Three-way repeated measures parameters for action potential firing as a function of current injection. Bold indicates $P<0.05$.

\begin{tabular}{|c|c|c|c|}
\hline & 3-way & $\begin{array}{l}\text { 2-way (sex } \\
\text { consolidated) }\end{array}$ & $\begin{array}{l}\text { 2-way } \\
\text { (gonadectomized } \\
\text { (GDX) consolidated) }\end{array}$ \\
\hline current step (pA) & $\begin{array}{l}F(2.554,91.96)=641.8 \\
P<0.0001\end{array}$ & $\begin{array}{l}F(10,380)=653 \\
P<0.0001\end{array}$ & $\begin{array}{l}F(10,380)=636 \\
P<0.0001\end{array}$ \\
\hline 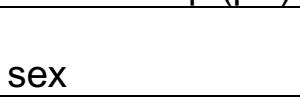 & $\begin{array}{l}F(1,36)=2.447 \\
P=0.1265\end{array}$ & $\begin{array}{l}F(1,38)=2.6 \\
P=0.1119\end{array}$ & \\
\hline GDX & $\begin{array}{l}F(1,36)=0.4993 \\
P=0.4844\end{array}$ & & $\begin{array}{l}F(1,38)=0.64 \\
P=0.4271\end{array}$ \\
\hline$p A x \operatorname{sex}$ & $\begin{array}{l}F(10,360)=1.758 \\
P=0.0668\end{array}$ & $\begin{array}{l}F(10,380)=1.9 \\
P=0.0477\end{array}$ & \\
\hline $\mathrm{pA} \times \mathrm{GDX}$ & $\begin{array}{l}F(10,360)=0.7544 \\
P=0.6728\end{array}$ & & $\begin{array}{l}F(10,380)=0.88 \\
P=0.5513\end{array}$ \\
\hline $\operatorname{sex} x$ GDX & $\begin{array}{l}F(1,36)=0.2066 \\
P=0.6522\end{array}$ & & \\
\hline $\mathrm{pA} x \operatorname{sex} x \mathrm{GDX}$ & $\begin{array}{l}F(10,360)=0.5547 \\
P=0.8503\end{array}$ & & \\
\hline
\end{tabular}


Table 6. Two-way ANOVA parameters for action potential properties

\begin{tabular}{|l|l|l|l|}
\hline Property & Sex & Gonadal Status & Interaction \\
\hline & $\mathrm{F}(1,37)=1.463 ;$ & $\mathrm{F}(1,37)=0.7278 ;$ & $\mathrm{F}(1,37)=0.6354 ;$ \\
max frequency & $\mathrm{P}=0.2341$ & $\mathrm{P}=0.3991$ & $\mathrm{P}=0.4305$ \\
\hline & $\mathrm{F}(1,37)=0.6163 ;$ & $\mathrm{F}(1,37)=0.1470 ;$ & $\mathrm{F}(1,37)=0.2182 ;$ \\
baseline & $\mathrm{P}=0.4374$ & $\mathrm{P}=0.7036$ & $\mathrm{P}=0.6431$ \\
\hline & $\mathrm{F}(1,37)=0.7224 ;$ & $\mathrm{F}(1,37)=0.001493 ;$ & $\mathrm{F}(1,37)=0.002371 ;$ \\
threshold & $\mathrm{P}=0.4008$ & $\mathrm{P}=0.9694$ & $\mathrm{P}=0.9614$ \\
\hline & $\mathrm{F}(1,37)=2.778 ;$ & $\mathrm{F}(1,37)=7.015 \mathrm{e}-$ & $\mathrm{F}(1,37)=0.8335 ;$ \\
rheobase & $\mathrm{P}=0.1040$ & $005 ; \mathrm{P}=0.9934$ & $\mathrm{P}=0.3672$ \\
\hline & $\mathrm{F}(1,37)=0.1120 ;$ & $\mathrm{F}(1,37)=0.1392 ;$ & $\mathrm{F}(1,37)=0.1060 ;$ \\
AP latency & $\mathrm{P}=0.7398$ & $\mathrm{P}=0.7112$ & $\mathrm{P}=0.7466$ \\
\hline & $\mathrm{F}(1,37)=1.173 ;$ & $\mathrm{F}(1,37)=0.9688 ;$ & $\mathrm{F}(1,37)=0.4683 ;$ \\
AP amplitude & $\mathrm{P}=0.2858$ & $\mathrm{P}=0.3314$ & $\mathrm{P}=0.4980$ \\
\hline & $\mathrm{F}(1,37)=2.817 ;$ & $\mathrm{F}(1,37)=3.069 ;$ & $\mathrm{F}(1,37)=2.858 ;$ \\
AP FWHM & $\mathrm{P}=0.1017$ & $\mathrm{P}=0.0881$ & $\mathrm{P}=0.0993$ \\
\hline & $\mathrm{F}(1,37)=0.07317 ;$ & $\mathrm{F}(1,37)=0.2856 ;$ & $\mathrm{F}(1,37)=0.2910 ;$ \\
AP rate of rise & $\mathrm{P}=0.7883$ & $\mathrm{P}=0.5962$ & $\mathrm{P}=0.5928$ \\
\hline & $\mathrm{F}(1,37)=3.374 ;$ & $\mathrm{F}(1,37)=0.3165 ;$ & $\mathrm{F}(1,37)=0.1254 ;$ \\
AHP amp & $\mathrm{P}=0.0743$ & $\mathrm{P}=0.5771$ & $\mathrm{P}=0.7253$ \\
\hline
\end{tabular}


Figures and Legends
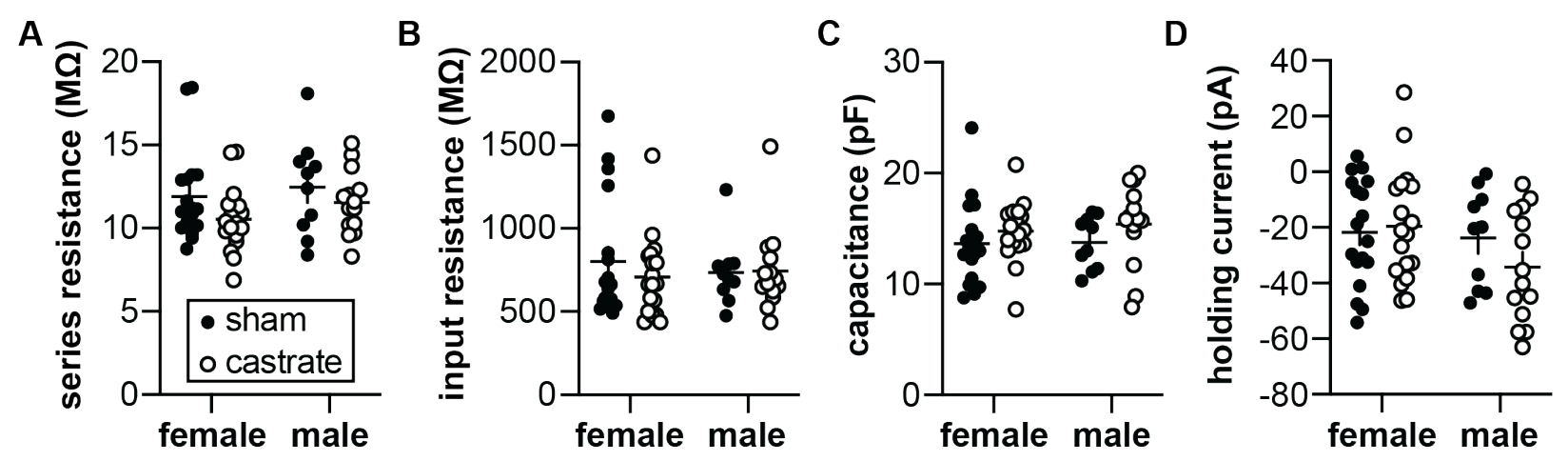

Figure 1. Passive properties of $\mathrm{GnRH}$ neurons in the potassium current experiments. No differences attributable to sex or gonadal status were detected in $(A)$ series resistance, $(B)$ input resistance, (C) capacitance or (D) holding current using two-way ANOVA (Table 1). 
A
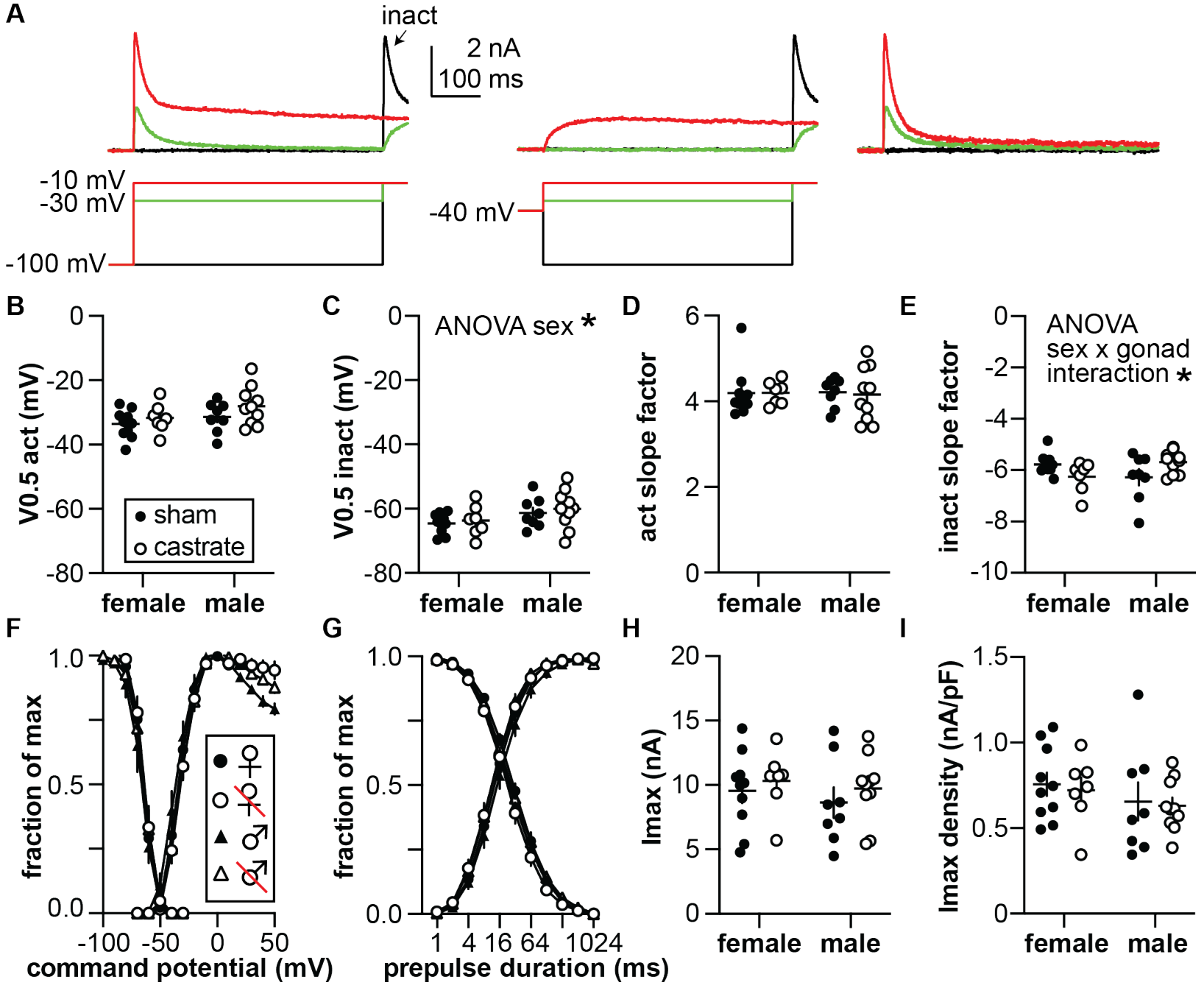

Figure 2. Characterization of the $I_{A}$ potassium current. (A) Representative traces illustrating the isolation of the rapidly inactivating $\mathrm{I}_{\mathrm{A}}$ (top) and the voltage protocols used (bottom). The $500 \mathrm{~ms}$ $100 \mathrm{mV}$ prepulse was truncated for illustration. The arrow labeled "inact" indicates the $-10 \mathrm{mV}$ test pulse at the end of the activation voltage family used to calculate the voltage dependence of inactivation. Only three steps from the voltage family from -100 to $+50 \mathrm{mV}$ are shown for clarity. The right panel shows $\mathrm{I}_{\mathrm{A}}$ isolated by subtracting the $-40 \mathrm{mV}$ prepulse traces in the middle panel from the $-100 \mathrm{mV}$ prepulse traces in the left panel. $(B, C)$ membrane potential at which half of the current is activated (V0.5act) (B) or inactivated (V0.5inact) (C). (D, E) activation (act) (D) and inactivation (inact) (E) slope factors. (F) Voltage dependence of activation and inactivation, normalized by maximum conductance and maximum current respectively. (G) Time course of recovery and inactivation, normalized by maximum current. $(H, I)$ Maximum current $(I m a x)(H)$ and current density (I). Statistical parameters are in Table 2. 
A

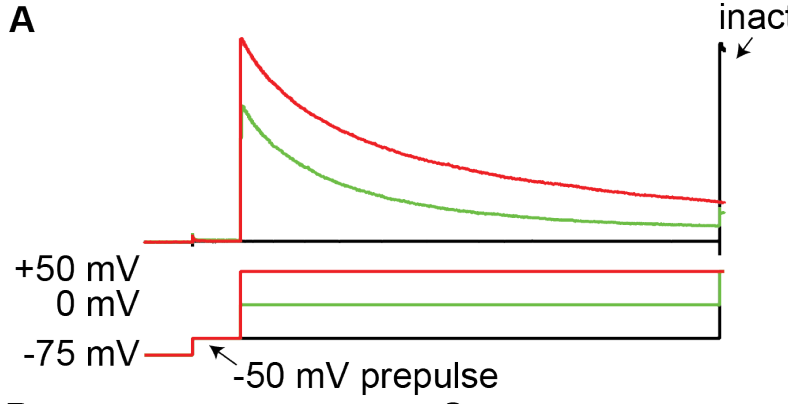

inact

$$
\begin{aligned}
& 2 \mathrm{nA} \\
& 1 \mathrm{~s} \\
& \hline
\end{aligned}
$$

C
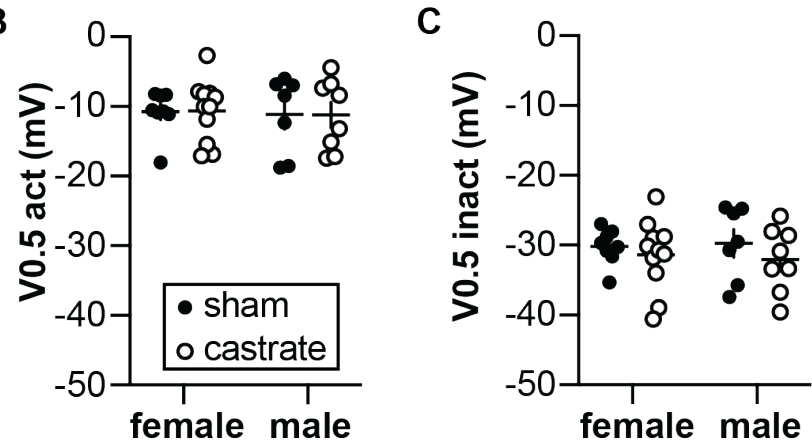

$\mathbf{F}$

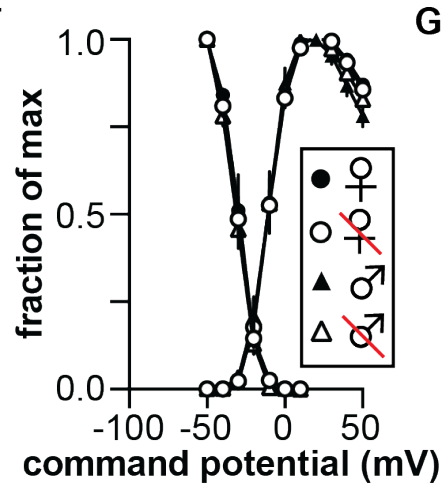

G

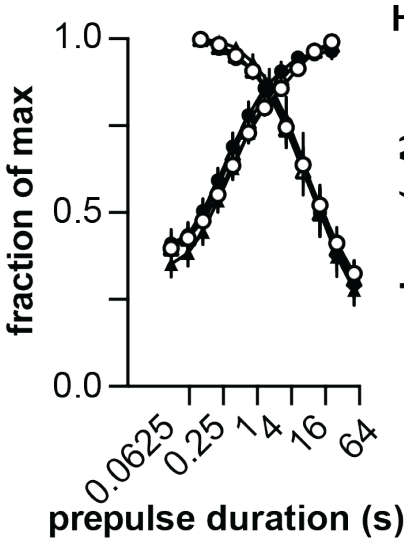

$+50 \mathrm{mV}$

$0 \mathrm{mV}$

$-50 \mathrm{mV}$

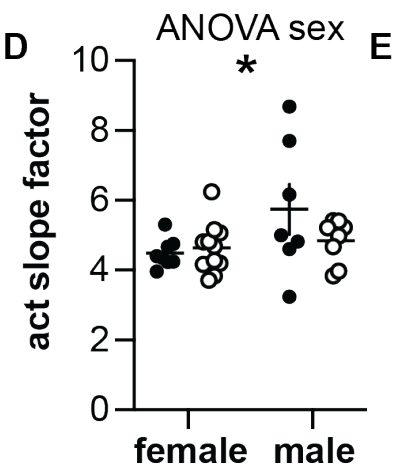

$E$

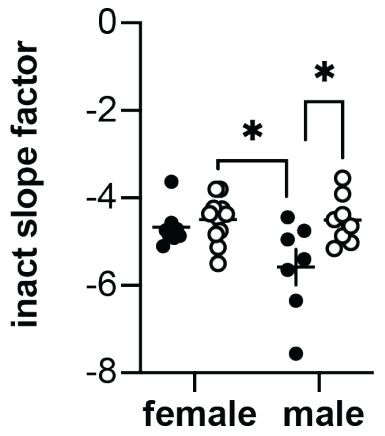

H 15
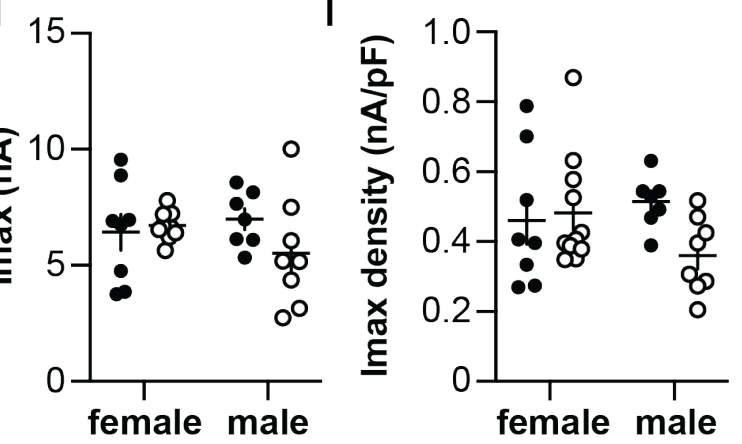

Figure 3. Characterization of the $I_{k}$ potassium current. (A) Representative traces illustrating the activation and inactivation of $I_{K}$, (top) and the voltage protocols used (bottom). The $10 \mathrm{~s}-75 \mathrm{mV}$ prepulse was truncated in the left panel for illustration. The arrow labeled "inact" on the left panel indicates the region expanded on the right. Only three steps of the voltage family from 100 to $+50 \mathrm{mV}$ are shown for clarity. $(\mathrm{B}, \mathrm{C})$ membrane potential at which half of the current is activated (V0.5act) (B) or inactivated (V0.5inact) (C). (D, E) activation (act) (D) and inactivation (inact) (E) slope factors. (F) Voltage dependence of activation and inactivation, normalized by maximum conductance and maximum current respectively. (G) Time course of recovery and inactivation, normalized by maximum current. $(\mathrm{H}, \mathrm{I})$ Maximum current $(\mathrm{Imax})(\mathrm{H})$ and current density (I). Statistical parameters are in Table 3. 

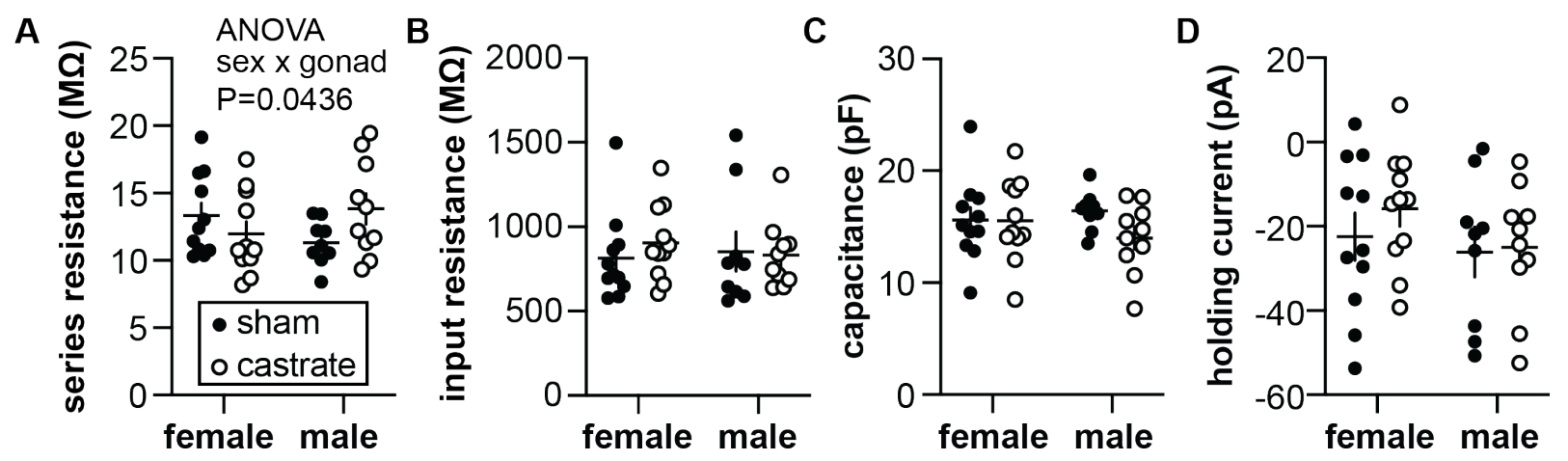

Figure 4. Passive properties of recordings for the action potential study. (A) series resistance (no post hoc comparisons were significant); (B) input resistance; (C) capacitance; (D) holding current at $-65 \mathrm{mV}$. 


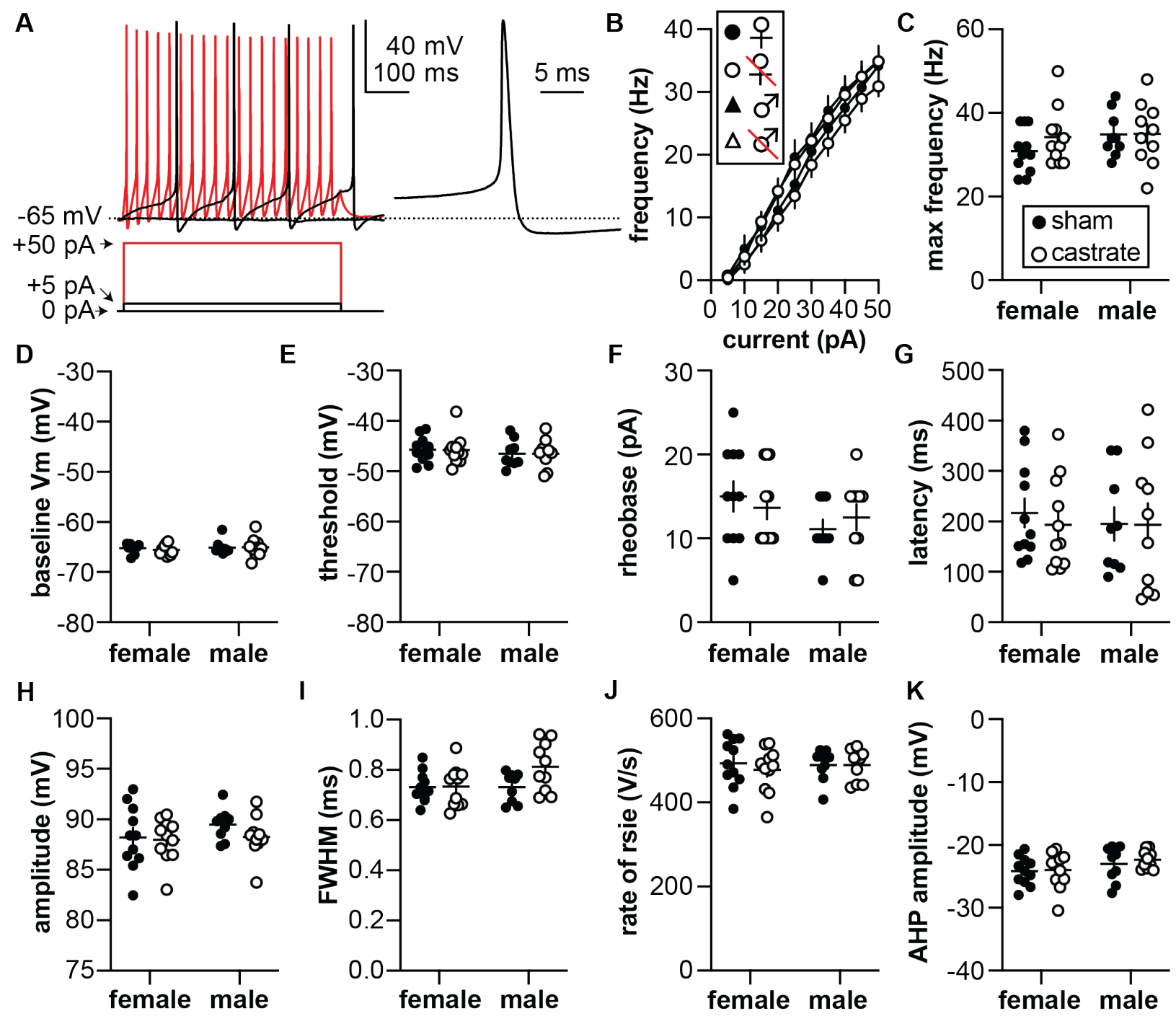

Figure 5. Action potential properties. (A) (left) Representative membrane voltage (top) responses to current injections (bottom); only three steps are shown for clarity. (Right) Expanded first action potential waveform. (B) Frequency of action potentials as a function of current injection. (C) Maximum action potential frequency. (D) Baseline membrane potential before rheobase current injection. (E) Action potential threshold. (F) Rheobase (minimum current to produce an action potential). (G) Action potential latency. $(\mathrm{H})$ Action potential amplitude. (I) Action potential full width at half maximum (FWHM). (J) Maximum rate of rise of the action potential. (K) Amplitude of the afterhyperpolarization. Note $y$-axes of $D, E$, and $H$ do not start or end at zero. Statistical parameters are in Tables 5 and 6. 